1. MBBS, DO, FCPS (Ophthalmology) Eye Specialist

PAF Base Hospital Rafiqui Shorkot.

2. MBBS, DO, MCPS, FCPS

(Ophthalmology)

Classified Eye Specialist, AFIO Rawalpindi.

3. MBBS, DO, FCPS (Ophthalmolgy) Eye Specialist

PAF Base Hospital Faisal, Karachi.

4. MBBS

Registrar (Medicine)

Aziz Bhatti Shaheed Teaching

Hospital Gujrat.

5. MBBS, DO, FCPS (Ophthalmology)

Eye Specialist Combined Military

Hospital Okara.

6. MBBS, FCPS (E.N.T)

ENT Specialist

PAF Base Hospital Lahore.

Correspondence Address:

Dr. Zulfiqar Ahmed Memon

Eye Specialist

PAF Base Hospital Rafiqui (Shorkot)

Jhang.

zulfi4eye@gmail.com

Article received on:

30/03/2017

Accepted for publication:

15/09/2017

Received after proof reading:

29/11/2017

\section{CATARACT SURGERY;}

COMPARISON OF TOPICAL NEPAFENAC OPHTHALMIC SUSPENSION 0.1\% WITH TOPICALPREDNISOLONEACETATE 1\% INTHE MANAGEMENT OF POSTOPERATIVE INFLAMMATION

\section{Zulfiqar Ahmed Memon', Omar Zafar'2, Arsalan Farooq ${ }^{3}$, Shabnam Memon ${ }^{4}$, Najam ul Hassan ${ }^{5}$,} M. Tahir Shah

ABSTRACT... Objectives: To determine the efficacy of topical nepafenac $0.1 \%$ eye drops as compared toprednisolone acetate $1 \%$ eye drops in the management of postoperative inflammation after cataract surgery. Study Design: Randomized controlled clinical study. Place and Duration of study: Pakistan air force hospital Rafiqui from Oct 2016 to Feb 2017. Patients and methods: Two hundred and forty eight eyes were randomly divided in two equal groups. Patients received nepafenac $0.1 \%$ or prednisolone acetate $1 \%$ as single drop 8 hourly beginning 1 day preoperatively, continued till 2 weeks post-operatively. Efficacy of the drug will be considered if there is no anterior chamber reaction along with no aqueous flare after 2 weeks of treatment. Results: $85.5 \%$ of cases resolved with topical nepafenac $0.1 \%$ as compared to $88.7 \%$ that were cured with prednisolone acetate $1 \%$. Pearson chi square test indicates that there is no statistical significant difference $(p=0.449)$ between the efficacy of two modes of treatment. Conclusion: Nepafenac $0.1 \%$ eye drops are as effective as prednisolone acetate $1 \%$ in the prevention of postoperative inflammation with cataract surgery.

Key words: Cataract, Inflammation, Prednisolone, Steroids, Nepafenac, NSAIDs (Nonsteroidal anti-inflammatory drugs).

Article Citation: Memon ZA, Zafar O, Farooq A, Memon S, Najam ul Hassan, Shah MT. Cataract surgery; Comparison of topical nepafenac ophthalmic suspension $0.1 \%$ with topical prednisolone acetate $1 \%$ in the management of postoperative inflammation. Professional Med J 2017;24(12):1812-1817. DOI:10.17957/TPMJ/17.3940

\section{INTRODUCTION}

$51 \%$ of world blindness is secondary to cataract and it constitutes almost 20 million individuals. ${ }^{1}$ Phacoemulsification is a modern technique for cataract surgery, however as a result of surgical trauma to the eye during cataract surgery, concentration of prostaglandins (PGs) $E$ and $F$ are increased in aqueous humor. ${ }^{2}$ manifesting as circumcilliary injection, anterior chamber reaction, flare and pain. This reaction is usually self-limited but may result in cystoid macular edema, uveitic glaucoma and posterior capsular opacification. For prevention of these complications topical antiinflammatory drugs are used after the surgery. Most common of them are steroids ${ }^{3}$ though nonsteroidal anti-inflammatory agents (NSAIDs) are also effective. ${ }^{4}$

For last half century corticosteroids are used for ocular inflammation. They are used to suppress ocular inflammation in trauma, uveitis as well as after most ocular surgical procedures. However, they are not free from adverse effects, especially an increase intraocular pressure (IOP), delayed wound healing and increase risk of infection. This raised IOP could lead to glaucomatous opticneuropathy. ${ }^{5}$

Individual response to steroids is highly dependent on the duration, strength and frequency of therapy and the potency of the agent used. The elevation of IOP is unlikely before 1 week of treatment and rarely occurs in less than 2 weeks. However, until all these agents are compared in a model of ocular inflammation relevant to human disease, no conclusion can be reached. ${ }^{6}$ The IOP fluctuations are more usual with dexamethasone and other older steroids. Among the clinically available corticosteroid preparations, Prednisolone acetate $1 \%$ is widely used following cataract surgery and has excellent ocular penetration. We chose the acetate analogue of prednisolone since it is 
more hydrophobic and its concentration peaks in anterior chamber $(669.6 \mathrm{ng} / \mathrm{ml})$ in $91-120 \mathrm{mins}$ and remains in its therapeutic levels over 12 hours.

Non-steroidal anti-inflammatory drug (NSAIDs) are potent inhibitors of cyclooxygenase enzymes and are available in topical form to be used for postoperative inflammation and macular oedema. Prostaglandins disturb the blood-ocular barrier, cause vasodilation, and help in migration of white blood cells. Their biosynthesis is catalyzed by Cyclooxygenase, a critical enzyme in the inflammatory process. Nepafenac is an NSAID that possesses a good corneal penetrance property and achieves high aqueous concentration. In the drug it is in inactive form and converts to its It is a prodrug that is metabolized into its active component, amfenac, once instilled in the conjunctival sac. ${ }^{4}$ Like other NSAIDs it inhibits production of prostaglandin by deactivating cyclooxygenase (COX). Its action starts from 5-10 mins with a peak action between 40 to 80 mins, which lasts at least for 8 hours.

In our study we have compared the efficacy of two drugs, prednisolone acetate and nepafenac ophthalmic suspension, to control intraocular inflammation after the cataract surgery secondary to surgical trauma. Rationale of our study is to provide a single drug for control of post-operative intraocular inflammation, without any added risk of raising intraocular pressure.

\section{MATERIALS AND METHODS}

\section{Study design}

This study was conducted at Pakistan Air Force Base Hospital Rafiqui (Shorkot) from Oct 2016 to Feb 2017.Approval from the institutional ethical committee was obtained and informed consent was taken from the participants.

Inclusion criteria were age more than 50 years and nuclear cataract density of 2-4 by LOCSIII. ${ }^{7}$ Patients with secondary cataract, history of diabetes, hypertension, uveitis, use of systemic steroids or NSAIDs or previous intraocular surgery were excluded from the study.

248 eyes fulfilling the laid down criteria were enrolled in this study and divided into two equal groups by using randomized sampling. One group received topical prednisolone acetate $1 \%$ while the other received nepafenac $(0.1 \%)$ one drop TDS daily starting one day preoperatively, till 2 weeks post-operatively. Along with this moxifloxacin $(3 \%)$ was prescribed four times daily for two weeks, with at least 05 minutes interval between two drugs. Preoperative mydriasis was achieved with topical tropicamide (1.0\%). Anesthesia was performed with topical procainamide hydrochloride $(0.5 \%)$.

Phacoemulsification using OPTIKON ${ }^{\circledR} \quad$ (The Pulsar - MinimalStress) was performed by a single ophthalmologist using standardized $1.0 \mathrm{~mm}$ and $2.75 \mathrm{~mm}$ clear corneal incisions with stop-chop technique and foldable IOLs were inserted in the bag. Moxifloxacin $0.05 \mathrm{ml}$ undiluted was given intracamerally to each patient in both groups at the end of the surgery.

Best-corrected visual acuity (BCVA) and intraocular pressure (IOP) measurement, slit lamp examination along with flare cell measurement were performed preoperatively, followed by post operative day 1, 3, $7 \& 14$. Vitals signs including Blood Pressure and Pulse were measuredsimilarly on day $1,3,7 \& 14$ (if required). Pre-operative investigations were carried out.

The primary variable was the efficacy which was defined as the individuals with no aqueous cells and no aqueous flare at post-operative day 14 . While the aqueous cell and aqueous flare grading were considered as secondary variables.

Grading of cells and Flare was performed with a $2 \mathrm{~mm}$ long and $1 \mathrm{~mm}$ wide slit beam with maximal light intensity and magnification. Total no of cells within the field were counted and Flare was graded clinically by observing the degree of interference in the visualization of iris and classified according to Tabl-I. ${ }^{8}$

For the primary variables of efficacy at day 14 , a Chi-square test of independence was performed for significance assessment. The analysis of aqueous cells and flare grading was 
conducted with a repeated analysis of variance at all postsurgical follow ups. For comparisons in aqueous cells and flare grading at baseline between the groups, two-sample $t$ test was performed. A Chi-Square test was performed for the comparison of Demographics data. $P$ value less than $\leq 0.05$ is considered significant. SPSS v13.0 was used for analyzing the data.

\section{RESULTS}

A total number of 248 patients, fulfilling the inclusion and exclusion criteria, were recruited for the study which were divided in two equal groups. There were 124 patients in the prednisolone acetate group of which $48.4 \%$ were males and $51.6 \%$ were females (Table-II) while in nepafenac group comprised of $53.2 \%$ were males and $46.8 \%$ were females.

The mean age was $58.19 \pm 4.90$ years for the prednisolone group and $59.89 \pm 5.49$ years for the nepafenac group (Table-III).

Gender or age of the patients between treatment

groups revealed no statistically significance. ( $P>$ 0.05, both comparisons).

The efficacy at 14th post-operative day was compared. Preoperatively there was no reaction or aqueous flare in both groups thus comparable with each other. Post-operative aqueous cells and flare grades and the statistical analyses on day- 1 and day-14 grades of both groups are presented in Table-IV.

In prednisolone group $88.7 \%$ patients showed no cells or flare in the anterior chamber as compared to $85.5 \%$ in nepafenac group post-operatively. While rest of all patients showed traces of cells in the anterior chamber with no flare. The analysis showed no significance difference in the efficacy in two groupsat day 14, demonstrating the comparable effectiveness of both treatment modalities in reducing postoperative inflammation $(p<0.05)$. The results are summarized in Table-V.

$$
\begin{array}{lll}
\text { Chi square } & = & 0.574 \\
\mathrm{P} \text { value } & = & 0.449
\end{array}
$$

\begin{tabular}{c|c|c|}
\hline Grade & Cells in AC & Aqueous flare \\
\hline $\mathbf{0}$ & $<1$ & Nil \\
\hline $\mathbf{+ 1}$ & $1-5$ & Just detectable \\
\hline $\mathbf{+ 2}$ & $6-15$ & Moderate (iris and lens details clear) \\
\hline $\mathbf{+ 3}$ & $16-30$ & Marked (iris and lens details hazy) \\
\hline $\mathbf{+ 4}$ & $>30$ & Intense (fibrinous exudate) \\
\hline & \multicolumn{2}{|c|}{ Table-l. Grading of anterior chamber cells and aqueous flare } \\
\hline
\end{tabular}

\begin{tabular}{|l|c|c|c|c|}
\hline & \multicolumn{2}{|c|}{$\begin{array}{c}\text { Prednisolone acetate 1\% } \\
\text { (Group-A) }\end{array}$} & \multicolumn{2}{c|}{$\begin{array}{c}\text { Nepafenac ophthalmic solution } \mathbf{0 . 1 \%} \\
\text { (Group-B) }\end{array}$} \\
\hline
\end{tabular}

\begin{tabular}{|c|c|c|c|c|c|}
\hline \multirow{2}{*}{ Age in Years } & \multicolumn{2}{|c|}{$\begin{array}{l}\text { Prednisolone acetate } 1 \% \\
\text { (Group-A) }\end{array}$} & \multicolumn{2}{|c|}{$\begin{array}{l}\text { Nepafenac ophthalmic solution } 0.1 \% \\
\text { (Group-B) }\end{array}$} & \multirow[b]{2}{*}{$\begin{array}{c}P-\text { value } \\
\text { (Chi Square) }\end{array}$} \\
\hline & Number & Percent & Number & Percent & \\
\hline $51-60$ & 86 & $69.4 \%$ & 70 & $56.5 \%$ & \multirow{3}{*}{0.106} \\
\hline $61-70$ & 37 & $29.8 \%$ & 53 & $42.7 \%$ & \\
\hline$>70$ & 01 & $0.8 \%$ & 01 & $0.8 \%$ & \\
\hline Total & 124 & $100.0 \%$ & 124 & $100.0 \%$ & \\
\hline Mean $\pm S D$ & \multicolumn{2}{|c|}{$58.19 \pm 4.90$} & \multicolumn{2}{|c|}{$59.89 \pm 5.49$} & \\
\hline \multicolumn{6}{|c|}{ Table-III. Distribution of patients by age $n=248$} \\
\hline
\end{tabular}

Table-II. Distribution of gender $n=248$ 


\begin{tabular}{|c|c|c|c|c|c|c|c|}
\hline \multirow{3}{*}{$\begin{array}{l}\text { Day1 } \\
\text { cells } \\
\text { (Grade) }\end{array}$} & \multirow{2}{*}{\multicolumn{2}{|c|}{$\begin{array}{c}\text { Group } \\
\text { Prednisolone Acetate }\end{array}$}} & $\mathbf{N}$ & Mean & Std. Deviation & Std. Error Mean & \multirow{3}{*}{$\begin{array}{c}\text { P value ( } \mathrm{t} \text { - Test) } \\
0.168\end{array}$} \\
\hline & & & 124 & 1.56 & .725 & .065 & \\
\hline & \multicolumn{2}{|r|}{$\begin{array}{l}\text { Nepafenac Ophthalmic } \\
\text { Solution }\end{array}$} & 124 & 1.65 & .699 & .063 & \\
\hline \multirow{2}{*}{$\begin{array}{l}\text { Day1 } \\
\text { flare } \\
\text { (Grade) }\end{array}$} & \multicolumn{2}{|r|}{ Prednisolone Acetate } & 124 & .56 & .641 & .058 & \multirow[b]{2}{*}{0.379} \\
\hline & \multicolumn{2}{|r|}{$\begin{array}{l}\text { Nepafenac Ophthalmic } \\
\text { Solution }\end{array}$} & 124 & .48 & .548 & .049 & \\
\hline \multirow[b]{2}{*}{$\begin{array}{l}\text { Day14cells } \\
\text { (Grade) }\end{array}$} & \multicolumn{2}{|r|}{ Prednisolone Acetate } & 124 & .13 & .382 & .034 & \multirow[b]{2}{*}{0.420} \\
\hline & \multicolumn{2}{|c|}{$\begin{array}{l}\text { Nepafenac Ophthalmic } \\
\text { Solution }\end{array}$} & 124 & .19 & .483 & .043 & \\
\hline \multirow{2}{*}{$\begin{array}{l}\text { Day14flare } \\
\text { (Grade) }\end{array}$} & \multicolumn{2}{|r|}{ Prednisolone Acetate } & 124 & .02 & \multirow{2}{*}{$\begin{array}{l}.126 \\
.198\end{array}$} & .011 & \multirow[b]{2}{*}{0.251} \\
\hline & \multicolumn{2}{|r|}{$\begin{array}{l}\text { Nepafenac Ophthalmic } \\
\text { Solution }\end{array}$} & 124 & .04 & & .018 & \\
\hline \multicolumn{8}{|c|}{ Table-IV. Efficacy statistics $n=248$} \\
\hline \multirow[t]{2}{*}{ Efficacy } & \multicolumn{4}{|c|}{$\begin{array}{l}\text { Prednisolone acetate } 1 \% \\
\text { (Group-A) }\end{array}$} & \multicolumn{3}{|c|}{$\begin{array}{l}\text { Nepafenac ophthalmic solution } 0.1 \% \\
\text { (Group-B) }\end{array}$} \\
\hline & \multicolumn{3}{|c|}{ Number } & \multicolumn{2}{|c|}{ Percent } & mber & Percent \\
\hline Yes & & 110 & & 88.7 & & 06 & $85.5 \%$ \\
\hline No & & 14 & & $11.3^{c}$ & & 18 & $14.5 \%$ \\
\hline Total & & 124 & & & & 24 & \\
\hline
\end{tabular}

\section{DISCUSSION}

Steroids are considered as major treatment modality for most of the ocular inflammatory conditions since 1964 as studied by Ormsby et al. He determined the role of ACTH and cortisone in uveitis, keratitis, and allergic conjunctivitis.

Fong et al studied role of Loteprednol etabonate gel $0.5 \%$ inreducing pain and anterior chamber reaction after cataract surgery in 2012. ${ }^{3}$ They concluded Loteprednol etabonate gel $0.5 \%$ was effective in the management of postoperative inflammation and pain.

Chronic use of topical steroids in young individuals with vernal kerato conjunctivitis showed glaucoma among $8.7 \%$ of the study participants ${ }^{9}$ The raised intraocular pressure settled down after two months of halting the treatment with steroids, thus signifying their association.

To obviate the local and systemic side effects of topical steroids, search for an alternative was obligatory. In August 2013 a review was published in British Medical Journal. In this review the authors concluded "It seems unlikely that the long-term future of therapy lies in corticosteroids, but instead that this increased knowledge will offer the opportunity for effective targeted treatment of the molecular mechanisms underlying ocular inflammation whilst minimizing local and systemic side-effects". ${ }^{10}$

Second most important class of drug studied so far is NSAIDs. One of the earliest drug used in this class was diclofenac. C-G Laurell compared the effects of dexamethasone, diclofenac, or placebo on the inflammatory response after cataract surgery in 2002. They concluded that dexamethasone and diclofenac were equally effective and significantly better than placebo and recommended the use of anti-inflammatory agents after cataract surgery. ${ }^{11}$

Though very effective the diclofenac was associated with corneal melting with long term use thus waned off from the market. Guidera et al studied Keratitis, ulceration, and perforation associated with topical NSAIDs and concluded their association. ${ }^{12}$

Several generations of the NSAIDs have been approved for use topically in ophthalmology, nepafenac is one them. It is a prodrug (base) which is converted to its active form amfenac. It differs from other available NSAIDs by its lipid solubility. 
The ophthalmic NSAID, including flurbiprofen, diclofenac sodium, ketorolac, and bromfenac, does not penetrates the intact corneal epithelium as they are relatively water-soluble phenylalkanoic and phenylacetic acids. Nepafenac ophthalmic suspension exists as a base in tear film and therefore penetrates the cornea well. Gamache et al. verified its penetration in cornea and validated its distribution in all ocular tissues in an animal based study. ${ }^{13}$

M Nardi et al found nepafenac and ketorolac $0.5 \%$ equally effective in the prevention and treatment of postoperative ocular pain and inflammation. ${ }^{14}$ Jiro Numaga found nepafenac ophthalmic suspension more effective than placebo for inflammatory reaction as well as pain post operatively, and recommended it as an essential entity to be used following cataract surgery. ${ }^{4}$

Lindstrom R, Kim T studied Ocular permeation and inhibition of retinal inflammation: an examination of data and expert opinion on the clinical utility of nepafenac. They suggested the use of nepafenac for anterior uveitis and cystoid macular oedema after cataract surgery. ${ }^{15}$

Guadalupe Cervantes-Coste et al also concluded the use of nepafenac in reducing the chance of macular oedema post operatively. ${ }^{16}$

Melissa Cable studied Comparison of bromfenac $0.09 \%$ to nepafenac $0.1 \%$ post-operatviely. ${ }^{17}$ She concluded that both bromfenac and nepafenac resulted in comparable BCVA and macular thickness.

Topical NSAIDs when used in combination with topical corticosteroids delay wound healing, therefore, their combination may induce keratitis in predisposed individuals, which may lead to persistent corneal erosion, ulceration and perforation. ${ }^{18}$

In this study efficacy of prednisolone acetate $1 \%$, a topical steroid, was compared to topical nepafenac ophthalmic suspension, for resolution of intraocular inflammation after phacoemulsification. The subjects were patients with cataracts who presented in eye OPD of Pakistan Air Force Hospital Rafiqui (Shorkot) and undergone phacoemulsification and aspirations with intraocular lens implantation in posterior chamber within the capsular bag. Evaluations were based on the efficacy i.e. individuals with no aqueous cell and aqueous flare grading, on 14 days. The efficacy was $88.7 \%$ in prednisolone group and $85.5 \%$ in nepafenac group, revealing no difference that is statistically significance.

\section{CONCLUSION}

Nepafenac ophthalmic suspension $0.1 \%$ is as effective as prednisolone acetate $1 \%$ in reducing postoperative inflammation after cataract surgery without any added risk of increased intraocular pressure, epithelial breakdown, corneal thinning, corneal erosion, corneal ulceration or corneal perforation and added effect of prevention of cystoid macular oedema. We recommended to use this drug especially in cases where steroid are contraindicated e.g. Steroid responders, where NSAIDs are indicated especially when risk of macular oedema is inevitable.

Copyright 15 Sep, 2017.

\section{PROPRIETARY STATEMENT}

None of the authors has any commercial or proprietary interests in any of the steroid or non-steroidal anti-inflammatory preparations mentioned nor any other topical ophthalmic corticosteroid or non-steroidal anti-inflammatory drugs.

\section{REFERENCES}

1. World Health Organization. WHO statement on Prevention of Blindness and Visual Impairment [Internet]. 2016 [cited 2016 May17]. Available from: http://www.who.int/blindness/causes/priority/en/ index1.html.

2. Zanetti FR, Fulco EA, Chaves FR, da Costa Pinto AP, Arieta CE, Lira RP. Effect of preoperative use of topical prednisolone acetate, ketorolac tromethamine, nepafenac and placebo, on the maintenance of intraoperative mydriasis during cataract surgery: a randomized trial. Indian J Ophthalmol. 2012; 60(4):27781.

3. Fong R, Leitritz M, Siou-Mermet R, Erb T. Loteprednol etabonate gel $0.5 \%$ for postoperative pain and inflammation after cataract surgery: results of a 
multicenter trial. Clin Ophthalmol. 2012; 6:1113-24.

4. Numaga J. Phase II placebo-controlled study of nepafenac ophthalmic suspension $0.1 \%$ for postoperative inflammation and ocular pain associated with cataract surgery in Japanese patients. J Ophthalmic Inflamm Infect. 2011;1(4):14755.

5. Jain A, Liu X, Wordinger RJ, Yorio T, Cheng YQ, Clark AF. Effects of thailanstatins on glucocorticoid response in trabecular meshwork and steroid-induced glaucoma. Invest Ophthalmol Vis Sci. 2013;54(5):313742.

6. American Academy of Ophthalmology, Fundamentals and Principles of Ophthalmology: Ocular Pharmacotherapeutics. editors. Chalam KV, Ambati BK, Beaver HA, et al. San Francisco, CA: American Academy of Ophthalmology; 2012. pp.359-60.

7. Bencic G, Zoric-Geber M, Saric D, Corak M, Mandic Z. Clinical importance of the lens opacities classification system III (LOCS III) in phacoemulsification. Coll Antropol. 2005; 29 Suppl 1:91-4.

8. Jabs DA, Nussenblatt RB, Rosenbaum JT, Standardization of Uveitis Nomenclature Working G. Standardization of uveitis nomenclature for reporting clinical data. Results of the First International Workshop. Am J Ophthalmol. 2005; 140(3):509-16.

9. Mandal R, Maiti P, Sasmal NK, Sinha N, Gupta A, Das $\mathrm{KS}$, et al. Ocular effects of long term use of topical steroids among children and adolescents with vernal keratoconjunctivitis: a prospective observational study. J Indian Med Assoc. 2011; 109(10):708-10, $12-3$.

10. Tempest-Roe S, Joshi L, Dick AD, Taylor SR. Local therapies for inflammatory eye disease in translation: past, present and future. BMC Ophthalmol. 2013; 13(1):39.
11. Laurell CG, Zetterstrom C. Effects of dexamethasone, diclofenac, or placebo on the inflammatory response after cataract surgery. $\mathrm{Br} J$ Ophthalmol. 2002; 86(12):1380-4.

12. Guidera AC, Luchs JI, Udell IJ. Keratitis, ulceration, and perforation associated with topical nonsteroidal anti-inflammatory drugs. Ophthalmology. 2001; 108(5):936-44.

13. Gamache DA, Graff G, Brady MT, Spellman JM, Yanni JM. Nepafenac, a unique nonsteroidal prodrug with potential utility in the treatment of traumainduced ocular inflammation: I. Assessment of antiinflammatory efficacy. Inflammation. 2000; 24(4):35770.

14. Nardi M, Lobo C, Bereczki A, Cano J, Zagato E, Potts S, et al. Analgesic and anti-inflammatory effectiveness of nepafenac $0.1 \%$ for cataract surgery. Clin Ophthalmol. 2007; 1(4):527-33.

15. Lindstrom R, Kim T. Ocular permeation and inhibition of retinal inflammation: an examination of data and expert opinion on the clinical utility of nepafenac. Curr Med Res Opin. 2006; 22(2):397-404.

16. Cervantes-Coste G, Sanchez-Castro YG, Orozco-Carroll M, Mendoza-Schuster E, Velasco-Barona C. Inhibition of surgically induced miosis and prevention of postoperative macular edema with nepafenac. Clin Ophthalmol. 2009; 3:219-26.

17. Cable M. Comparison of bromfenac $0.09 \%$ QD to nepafenac $0.1 \%$ TID after cataract surgery: pilot evaluation of visual acuity, macular volume, and retinal thickness at a single site. Clin Ophthalmol. 2012; 6:997-1004.

18. Gaynes BI, Fiscella R. Topical nonsteroidal antiinflammatory drugs for ophthalmic use: a safety review. Drug Saf. 2002; 25(4):233-50.

\section{AUTHORSHIP AND CONTRIBUTION DECLARATION}

\begin{tabular}{|c|l|l|}
\hline Sr. \# & \multicolumn{1}{|c|}{ Author-s Full Name } & \multicolumn{1}{|c|}{ Contribution to the paper } \\
\hline 1 & Zulfiqar Ahmed Memon & Data collection, Procedure \\
\hline 2 & Omar Zafar & Original concept, Review \\
\hline 3 & Arsalan Farooq & Proof reading \\
\hline 4 & Shabnam Memon & Statistical analysis \\
\hline 5 & Najam ul Hassan & Literature Review \\
\hline 6 & M. Tahir Shah & Review
\end{tabular}

